\title{
$\bullet$ \\ Does Non Vegetarian Food Increases the Risk of COVID-19? - A Review
}

\section{IJCRR}

Section: Healthcare

Sci. Journal Impact

Factor: $6.1(2018)$

ICV: 90.90 (2018)

(c) (i) (3)

Copyright@IJCRR

\section{K. Sree Kala Priyadharsini ${ }^{1}$, Leslie Rani ${ }^{2}$, M. P. Brundha ${ }^{3}$, Lakshminarayanan Arivarasu ${ }^{4}$}

\begin{abstract}
'Saveetha Dental College, SIMATS, Chennai, Tamil Nadu, India; '2Lecturer, Department of General Pathology, Saveetha Dental College and Hos-

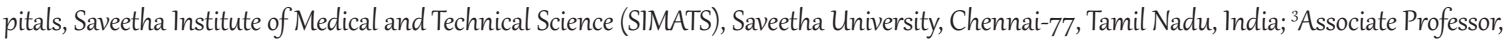
Department of Pathology, SIMATS, Chennai, Tamilnadu, India; ${ }^{4}$ Assistant Professor, Department of Pharmacology, Saveetha Dental College, SIMATS, Chennai, Tamilnadu, India.
\end{abstract}

\section{ABSTRACT}

Aim and Objectives: To review the relation of COIVD 19 occurrence with non-vegetarian diet.

Summary: Coronavirus is a viral disease that came from animal species to humans and now, it's spreading from human to human. Many people have believed that the consumption of non-vegetarian food, eggs can cause this infection. It was reported as saying that there's no truth in it. It spreads mainly from person to person and eating non-vegetarian food and eggs does not cause coronavirus infections. Limited access to fresh foods may lead to increased consumption of highly processed foods, which tend to be high in fats, sugars, and salt. Such changes in eating behavior could have a negative effect on the immune system, physical and mental health, and the well-being of individuals globally. There are a plethora of questions that arise in the realm of food and eating practices.

Conclusion: Until now, there is no evidence to indicate that non-veg food can transmit the infection. The spread or transmission of the virus through food has not yet been reported. All food should be cooked by the basic principles of food hygiene. This applies to both vegetarian and to non-vegetarian foods. Non-vegetarian foods - meats, fish, poultry, and eggs - should be cooked well before eating. Avoiding all raw preparations of fish and eggs must be considered. This review emphasizes the myth that is associated with non-veg in relation to COVID-19.

Key Words: Non-veg, COVID-19, Risk of infection, Awareness, Viral infections, Respiratory disease

\section{INTRODUCTION}

In late 2019, a pneumonia outbreak of uncertain etiology happened in Wuhan, China. There were many reports related to a live-animal and seafood market, supporting that the pathogens were transferred from animals to humans, rapidly evolving into transmission from human to human. The pathogen was classified as 2019 Novel Coronavirus (2019$\mathrm{nCoV})$, and the disease was named coronavirus Disease 2019 (COVID-19) ${ }^{1}$. Coronavirus disease 2019 (COVID-19) is an infectious disease caused by severe acute respiratory syndrome coronavirus 2 (SARS-CoV-2) $)^{2}$. The common clinical symptoms of the patients suffering from COVID-19 are fever, cough, shortness of breath, myalgia (muscle pain), tiredness, and lab CT, and the less usual symptoms are headache, production of sputum, hemoptysis, stomach pain, dizziness, nausea, diarrhea, and vomiting ${ }^{3}$. Some ENT (Ear, Nose, and Throat) doctors now believe that a distortion of the sense of taste (dysgeusia) and smell blindness (anosmia) could be considered as COVID-19 symptoms ${ }^{4}$. Disease onset can cause progressive respiratory failure because of alveolar impairment and even death ${ }^{5}$. Older age and the presence of underlying co-morbidities such as hypertension, diabetes, cardiovascular, and cerebrovascular disease are commonly correlated with worse prognosis ${ }^{6}$. This new virus is also more probable to result in serious respiratory diseases in older males ${ }^{7}$. Besides, most patients' chest CT demonstrated bilateral pneumonia with ground-glass opacity (GGO) and bilateral patchy shadows as the most typical patterns. The typical transmission pathways of COVID-19 contain direct transmissions such as sneezing, cough, and inhalation of small airborne particles and contact transmission, i.e. contact with the oral, eye, and nasal mucous membranes ${ }^{8}$. Although typical clinical presentations of COVID-19 do not contain eye symptoms, the examination of conjunctival samples from confirmed and suspected COVID-19 cases sup-

\section{Corresponding Author:}

Dr. M.P. Brundha, Associate Professor, Department of Pathology, SIMATS, Chennai, Tamil Nadu, India. Phone: 9884421482; E-mail: generalpath2015@gmail.com

ISSN: 2231-2196 (Print)

Received: 18.08.2020
ISSN: 0975-5241 (Online)

Revised: 20.09.2020
Accepted: 10.10 .2020
Published: 03.11 .2020 
ports that the transmission of COVID-19 is not restricted to the respiratory tract, and that eye exposure may be a potential way for the virus to penetrate. COVID-19 can also be transmitted by saliva directly or indirectly ${ }^{8,9}$. There's a myth that people who consume non-veg are highly susceptible to COVID-19.

Previous studies say that people who are vegetarians have $30 \%$ less mortality of respiratory diseases than people who consume non-veg ${ }^{10}$. Various dietary patterns have been linked to the risk of respiratory disease ${ }^{11}$. The "western" dietary pattern, prevalent in developed countries, is characterized by high consumption of refined red meats ${ }^{12}$. This form of intake has been associated with increased risk of asthma in children ${ }^{13}$. One possible mechanism for the association between processed meat intake, or more precisely, "cured meat" intake, and the risk of COPD is related to the nitrites added to meat products as preservatives and color fixatives ${ }^{14}$

The right nutrients in our diet can help you breathe easier, and in some cases, help minimize asthma symptoms ${ }^{15}$. While there's no specific diet recommendation for asthma, there are some foods and nutrients that may help support lung function and reduce asthma symptoms. Eggs are a rich source of vitamin $\mathrm{D}^{16}$. Vitamin D plays an important role in boosting immune system responses and helps to reduce airway inflammation. Low levels of vitamin D have been linked to increased risk of asthma attacks in children and adults. Processed meats have preservatives called nitrates, which extend their shelf life. They are not a healthy option for anyone but are especially bad for those suffering from COPD which leads to breathing difficulties ${ }^{17}$. Foods such as egg, shrimps, and other shellfish may cause allergy to some persons which may lead to asthma ${ }^{18}$. The aim of the study is to analyze if the consumption of non-veg increases the risk of COVID-19.

\section{Viral infections causing respiratory disease}

Respiratory viral infections are a leading cause of various diseases and mortality. The severity of these illnesses can vary markedly from mild or asymptomatic upper airway infections to severe wheezing, bronchitis, or pneumonia ${ }^{19}$. The mode of entry of these viruses can be nose, eyes, and ear. Infection in the eye produces an abscess called stye ${ }^{20}$. In most cases, respiratory viral infections are self-limiting and confined to the upper airways, where they evoke relatively mild symptoms such as sneezing and a runny nose ${ }^{21}$. However, in susceptible individuals, such as newborns and the elderly, the symptoms can impact on the lower airways, resulting in wheeze, shortness of breath, bronchiolitis, or pneumonia ${ }^{22}$. Common respiratory viral pathogens include adenovirus, enterovirus, human coronavirus, human metapneumovirus, rhinovirus (RV), influenza, para-influenza, and respiratory syncytial virus (RSV). Of these viruses, most genomic studies have focused on RSV, RV, and influenza ${ }^{23}$. This is because $\mathrm{RSV}$ is the most important cause of respiratory tract infec- tions leading to hospitalization among infants ${ }^{24}$. RV causes the majority of colds and around two-thirds of asthma exacerbations ${ }^{25}$. Influenza is the most common cause of pneumonia-related deaths in developed countries ${ }^{26}$. The pathogenesis of respiratory viral infections involves the complex interplay between viral virulence factors, environmental conditions, the magnitude, and temporal dynamics of the host response, and host susceptibility factors. Symptomatic infections are associated with increased viral shedding and a heightened host immune response ${ }^{27}$. Prevention of these infections can be minimized by using personal protective equipment ${ }^{28}$ The disproportionate impact of respiratory viral infections in early life and in individuals with chronic respiratory diseases like asthma can be explained by an aberrant host response. It is also apparent that the immune response whilst essential for viral control also promotes the expression of respiratory symptoms and causes collateral damage to the tissues, which in some cases can lead to mortality ${ }^{29}$.

\section{Origin and characteristics of COVID-19}

Coronaviruses belong to the Coronaviridae family in the Nidovirales order. Corona represents crown-like spikes on the outer surface of the virus; thus, it was named as a coronavirus. Coronaviruses are minute in size $(65-125 \mathrm{~nm}$ in diameter) and contain a single-stranded RNA as a nucleic material, size ranging from 26 to $32 \mathrm{kbs}$ in length. The subgroups of the coronaviruses family are alpha $(\alpha)$, beta $(\beta)$, gamma $(\gamma)$, and delta $(\delta)$ coronavirus. The severe acute respiratory syndrome coronavirus (SARS-CoV), H5N1 influenza A, H1N1 2009, and Middle East respiratory syndrome coronavirus (MERS-CoV) cause acute lung injury (ALI) and acute respiratory distress syndrome (ARDS) which leads to pulmonary failure and result in fatality. These viruses were thought to infect only animals until the world witnessed a severe acute respiratory syndrome (SARS) outbreak caused by SARS-CoV, 2002 in Guangdong, China ${ }^{30}$. Only a decade later, another pathogenic coronavirus, known as Middle East respiratory syndrome coronavirus (MERS-CoV) caused an endemic in Middle Eastern countries ${ }^{31}$. Recently at the end of 2019, Wuhan, an emerging business hub of China experienced an outbreak of a novel coronavirus that killed more than eighteen hundred and infected over seventy thousand individuals within the first fifty days of the epidemic. This virus was reported to be a member of the $\beta$ group of coronaviruses $^{32}$. The first known severe illness caused by a coronavirus emerged with the 2003 Severe Acute Respiratory Syndrome (SARS) epidemic in China ${ }^{33}$. A second outbreak of severe illness began in 2012 in Saudi Arabia with the Middle East Respiratory Syndrome (MERS). Recently, by the end of 2019, WHO was informed by the Chinese government about several cases of pneumonia with unfamiliar etiology. The outbreak was initiated from the Hunan seafood market in Wuhan city of China and rapidly infected more than 50 people. The live animals are frequently sold at the Hunan 
seafood market such as bats, frogs, snakes, birds, marmots, and rabbits. On 12 January 2020, the National Health Commission of China released further details about the epidemic, suggesting viral pneumonia. From the sequence-based analysis of isolates from the patients, the virus was identified as a novel coronavirus. Moreover, the genetic sequence was also provided for the diagnosis of viral infection.

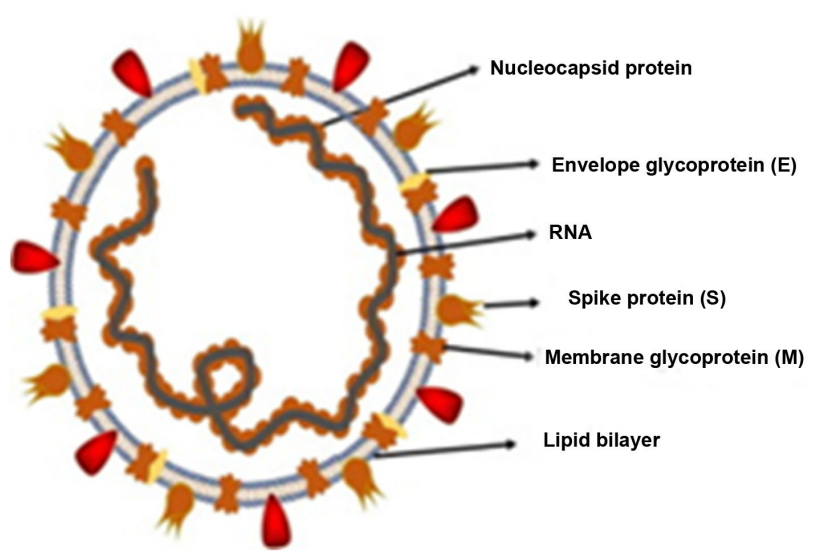

Figure 1: Structure of COVID-1930

\section{Non-vegetarian food}

Non-vegetarian is an Indian English word which refers to a meaty food where the major source is protein. Animal protein is good for health. Protein is very essential for healthy growth and has resistance power. Vegetables, rice, wheat are not rich resources of protein. They manage the intake by carbohydrate - protein ratio. They correct the energy level by meat-based foods and supply greater amounts of vitamin $\mathrm{B}_{12}{ }^{34}$ They maintain a healthy weight and correct their metabolism and reduce grain intake and provide better skin. Most non-vegetarian foods have high levels of protein, fats, and omega-3 fatty acids. Chicken and fish have not shown that it causes chronic diseases. Animal protein is a complete protein that has nine essential amino acids. The liver has vitamin $A$, vitamin $B_{12}$, iron, selenium, choline which has a role in brain, muscle-liver health ${ }^{35}$. Intake of red processed meat leads to obesity. The retention of muscle mass animal protein reduced the markers of inflammation. Better iron absorption if found in Meat. Heme iron present in the body absorbs better than non-heme iron found in plants. ${ }^{36}$

Non-vegetarian food strengthens the muscles and makes them grow faster. Meat is prestigious vital nutrition on one hand and dangerously immoral and potentially unhealthy on the other hand .Meat and chicken are rich sources of iron and control the blood flow. Iron deficiency anemia is mostly diagnosed in vegetarian ${ }^{37}$. Fishes have Omega-3 which sharpens the brains and helps in preventing cancer. Calcium will help in strengthening bones and teeth. Primary nutrients are needed for smooth functioning such as zinc and vitamins which push the body into self-repair mode, rebuild tissues, helps in rejuvenating skin, and maintains the central nervous system $^{38}$. They maintain body stamina and help in maintaining hemoglobin. A non-vegetarian diet is a good source of protein. However, protein found in cereal products such as nuts, pulses is incomplete. Meat, chicken, fish protects the body from excessive cold weather. Enhanced wisdom According to medical science, seafood, fish, and eggs, sharpen the intellect and promote smooth functioning of our brain and accelerates wisdom ${ }^{39}$. Non-veg food is rich in zinc, selenium which helps in tissue formation. Red meat and Fish have omega-3 which acts as a rejuvenating catalyst.

\section{Relation between Non-Veg and COVID-19}

There's a myth that eating non-veg leads to the infection of COVID-19. So, far there is no clear evidence supported by WHO to prove that the novel strain of the SARS-Cov-2 virus lives on chicken, eggs, meat, or seafood and can make non-vegetarian food unsafe for consumption. The SARS$\mathrm{CoV}-2$ viruses in fact need a host to grow and as far as food is concerned, currently, there is no evidence that food can be a route of transmission of the infection ${ }^{40}$.

In a recent press conference, All India Institute of Medical Science (AIIMS) Director Prof Randeep Guleria categorically stated that consumption of non-vegetarian foods or eggs does not cause infection. He further said that as a preventive measure meat should be thoroughly washed and cooked at the right temperature.

\section{Prevention}

The Centre of Disease Control and Prevention (CDC) had advised following certain precautionary measures: Before handling or eating food it is important to wash your hands with soap and water for 20 seconds, as a part of general food safety.

- Remember to handle and prepare food safely.

- Wash fruits and vegetables before eating.

- Store raw meat separately from other perishable foods in the refrigerator to avoid harmful microbes from raw foods spreading to cooked foods.

- Never consume raw or undercooked meat products.

- It is very important to wash the meat thoroughly and cook at high temperatures, as this helps to kill the harmful germs.

- Use different chopping boards for raw and cooked foods to avoid cross-contamination.

- Meat cooked at home and the right temperature is safe to be consumed.

- In case, if we are ordering food from outside, make sure it is prepared under proper hygienic conditions.

- Make sure to buy the eggs, poultry, fish from a trusted local vendor. Enquire where they have acquired it from. 


\section{Awareness}

Awareness must be created on border shutdowns and travel restrictions to prevent the spread of the disease among countries, symptomatic cases to remain at home for 14 days, avoidance of social contact from the symptomatic individual's awareness on social distancing, mass gathering control. Awareness by creating advertisements to explain the benefits of hand sanitizer in order to prevent the infection of COVID-19.

\section{FUTURE SCOPE}

As there is no evidence to prove that eating non-veg increases the risk of COVID-19 infection, many research work has to be carried out to prove the fact that consuming non-veg does not increase the risk of COVID-19. Genetics study can be carried out to break the rising myth of non-veg food in relation to COVID-19 and to understand the beneficial effects of nutrients in non-veg for building immunity.

\section{CONCLUSION}

In conclusion, there is no relation between non-veg and the risk of infection of COVID-19. Consuming non-veg food does not increase the risk of COVID-19. Well processed nonveg food has several health benefits. So, safe consumption has no risk of infection. Until now, there is no evidence to indicate that non-veg food can transmit the infection. The spread or transmission of the virus through food has not yet been reported. But as a precaution especially in India, it is a good idea, generally to avoid raw meat. It is better to have cooked meat. As of now, there is no advisory that prevents us from eating any non-vegetarian food. But it should always be a well-cooked food that should be safe enough.

\section{ACKNOWLEDGMENT}

Authors acknowledge the immense help received from the scholars whose articles are cited and included in references to this manuscript. The authors are also grateful to authors / editors / publishers of all those articles, journals, and books from which the literature for this article has been reviewed and discussed.

\section{Conflict of Interest: Nil}

Source of Funding: Nil

\section{REFERENCE}

1. Ge Z-Y, Yang L-M, Xia J-J, Fu X-H, Zhang Y-Z. Possible aerosol transmission of COVID-19 and special precautions in dentistry. Vol. 21, Journal of Zhejiang University-SCIENCE B. 2020. p. 361-8. Available from: http://dx.doi.org/10.1631/jzus.b2010010
2. Mp B, Brundha MP, Nallaswamy D. Hide and seek in pathology- A research on game-based histopathology learning. Vol. 10, International Journal of Research in Pharmaceutical Sciences. 2019. p. 1410-4. Available from: http://dx.doi.org/10.26452/ ijrps.v10i2.606

3. Peng $\mathrm{X}, \mathrm{Xu} \mathrm{X}, \mathrm{Li} \mathrm{Y}$, Cheng L, Zhou X, Ren B. Transmission routes of 2019-nCoV and controls in dental practice. Vol. 12, International Journal of Oral Science. 2020. Available from: http:// dx.doi.org/10.1038/s41368-020-0075-9

4. Prevalence of Dental Developmental Anomalies among Men and Women and its Psychological Effect in a Given Population - ProQuest . [cited 2020 Jun 7]. Available from: https://search. proquest.com/openview/1f488cc6e377096f44a87e509aceab79/ 1?pq-origsite $=$ gscholar \&cbl $=54977$

5. Xu H, Zhong L, Deng J, Peng J, Dan H, Zeng X, et al. High expression of ACE2 receptor of 2019-nCoV on the epithelial cells of oral mucosa. Vol. 12, International Journal of Oral Science. 2020. Available from: http://dx.doi.org/10.1038/s41368-0200074-x

6. Wang D, Hu B, Hu C, Zhu F, Liu X, Zhang J, et al. Clinical Characteristics of 138 Hospitalized Patients With 2019 Novel Coronavirus-Infected Pneumonia in Wuhan, China. Vol. 323, JAMA. 2020. p. 1061. Available from: http://dx.doi.org/10.1001/ jama.2020.1585

7. Chen N, Zhou M, Dong X, Qu J, Gong F, Han Y, et al. Epidemiological and clinical characteristics of 99 cases of 2019 novel coronavirus pneumonia in Wuhan, China: a descriptive study Vol. 395, The Lancet. 2020. p. 507-13. Available from: http:// dx.doi.org/10.1016/s0140-6736(20)30211-7

8. Rio C del, del Rio C, Malani PN. 2019 Novel Coronavirus-Important Information for Clinicians. Vol. 323, JAMA. 2020. p.1039. Available from: http://dx.doi.org/10.1001/ jama.2020.1490

9. Huang C, Wang Y, Li X, Ren L, Zhao J, Hu Y, et al. Clinical features of patients infected with 2019 novel coronavirus in Wuhan, China. Vol. 395, The Lancet. 2020. p. 497-506. Available from: http://dx.doi.org/10.1016/s0140-6736(20)30183-5

10. Key TJ, Appleby PN, Davey GK, Allen NE, Spencer EA, Travis RC. Mortality in British vegetarians: review and preliminary results from EPIC-Oxford. Vol. 78, The American Journal of Clinical Nutrition. 2003. p.533S - 538S. Available from: http:// dx.doi.org/10.1093/ajen/78.3.533s

11. Saadeh D, Salameh P, Baldi I, Raherison C. Diet and allergic diseases among population aged 0 to 18 years: myth or reality? Nutrients. 2013 Aug 29;5(9):3399-423.

12. Wood LG, Gibson PG. Dietary factors lead to innate immune activation in asthma. Vol. 123, Pharmacology \& Therapeutics. 2009. p.37-53. Available from: http://dx.doi.org/10.1016/j. pharmthera.2009.03.015

13. Carey OJ, Cookson JB, Britton J, Tattersfield AE. The effect of lifestyle on wheeze, atopy, and bronchial hyperreactivity in Asian and white children. Vol. 154, American Journal of Respiratory and Critical Care Medicine. 1996. p. 537-40. Available from: http://dx.doi.org/10.1164/ajrccm.154.2.8756835

14. Jakszyn P, Agudo A, Ibáñez R, García-Closas R, Pera G, Amiano P, et al. Development of a Food Database of Nitrosamines, Heterocyclic Amines, and Polycyclic Aromatic Hydrocarbons. Vol. 134, The Journal of Nutrition. 2004. p. 2011-4. Available from: http://dx.doi.org/10.1093/jn/134.8.2011

15. Brundha MP, Pathmashri VP, Sundari S. Quantitative Changes of Red Blood cells in Cancer Patients under Palliative Radiotherapy-A Retrospective Study. Vol. 12, Research Journal of Pharmacy and Technology. 2019. p. 687. Available from: http:// dx.doi.org/10.5958/0974-360x.2019.00122.7 
16. Timothy CN, Samyuktha PS, Brundha MP. Dental pulp Stem Cells in Regenerative Medicine - A Literature Review. Vol. 12, Research Journal of Pharmacy and Technology. 2019. p. 4052. Available from: http://dx.doi.org/10.5958/0974360x.2019.00698.x

17. Prashaanthi N, Brundha MP. A Comparative Study between Popplet Notes and Conventional Notes for Learning Pathology. Vol. 11, Research Journal of Pharmacy and Technology. 2018. p. 175. Available from: http://dx.doi.org/10.5958/0974360x.2018.00032.x

18. Kumar MDA, Ashok Kumar MD, Brundha MP. Awareness about nocturia-A questionnaire survey. Vol. 9, Research Journal of Pharmacy and Technology. 2016. p. 1707. Available from: http://dx.doi.org/10.5958/0974-360x.2016.00344.9

19. Hannah R, Ramani P, Brundha MP, Herald. J. Sherlin, Ranjith G, Ramasubramanian A, et al. Liquid Paraffin as a Rehydrant for Air Dried Buccal Smear . Vol. 12, Research Journal of Pharmacy and Technology. 2019. p. 1197. Available from: http://dx.doi. org/10.5958/0974-360x.2019.00199.9

20. P Jannathulferdioz BM. Awareness of Stye. Int J Pharm Sci Rev Res,. 40(1):30-2.

21. Zaas AK, Chen M, Varkey J, Veldman T, Hero AO, Lucas J, et al. Gene Expression Signatures Diagnose Influenza and Other Symptomatic Respiratory Viral Infections in Humans. Vol. 6, Cell Host \& Microbe. 2009. p. 207-17. Available from: http:// dx.doi.org/10.1016/j.chom.2009.07.006

22. Olenec JP, Kim WK, Salazar L, Pappas TE, Lee WM, Gern JE, et al. Weekly Monitoring of Children with Asthma for Infections and Illness During Common Cold Seasons. Vol. 125, Journal of Allergy and Clinical Immunology. 2010. p. AB150. Available from: http://dx.doi.org/10.1016/j.jaci.2009.12.588

23. Preethikaa S, Brundha MP. Awareness of diabetes mellitus among the general population. Vol. 11, Research Journal of Pharmacy and Technology. 2018. p. 1825. Available from: http:// dx.doi.org/10.5958/0974-360x.2018.00339.6

24. Kusel MMH, de Klerk NH, Holt PG, Kebadze T, Johnston SL, Sly PD. Role of respiratory viruses in acute upper and lower respiratory tract illness in the first year of life: a birth cohort study. Pediatr Infect Dis J. 2006 Aug;25(8):680-6.

25. Gern JE. How rhinovirus infections cause exacerbations of asthma . Vol. 45, Clinical \& Experimental Allergy. 2015. p. 32-42. Available from: http://dx.doi.org/10.1111/cea.12428

26. Newton AH, Cardani A, Braciale TJ. The host immune response in respiratory virus infection: balancing virus clearance and immunopathology. Vol. 38, Seminars in Immunopathology. 2016. p. 471-82. Available from: http://dx.doi.org/10.1007/s00281016-0558-0

27. Shreya S, Brundha MP. Alteration of Haemoglobin Value in Relation to Age, Sex and Dental Diseases-A Retrospective Correlation Study . Vol. 10, Research Journal of Pharmacy and Technology. 2017. p. 1363. Available from: http://dx.doi. org/10.5958/0974-360x.2017.00241.4
28. Ravichandran H, Brundha MP. Awareness about personal protective equipments in hospital workers (sweepers and cleaners). International Journal of Pharmaceutical Sciences Review and Research. 2016;40(1):28-9.

29. Kalaiselvi R, Brundha MP. Prevalence of hysterectomy in South Indian population. Vol. 9, Research Journal of Pharmacy and Technology. 2016. p. 1941. Available from: http://dx.doi. org/10.5958/0974-360x.2016.00398.x

30. Zhong NS, Zheng BJ, Li YM, Poon LLM, Xie ZH, Chan KH, et al. Epidemiology and cause of severe acute respiratory syndrome (SARS) in Guangdong, People's Republic of China, in February, 2003. Vol. 362, The Lancet. 2003. p. 1353-8. Available from: http://dx.doi.org/10.1016/s0140-6736(03)14630-2

31. Wang N, Shi X, Jiang L, Zhang S, Wang D, Tong P, et al. Structure of MERS-CoV spike receptor-binding domain complexed with human receptor DPP4 . Vol. 23, Cell Research. 2013. p. 986-93. Available from: http://dx.doi.org/10.1038/cr.2013.92

32. Muthukumar Balaji S, Brundha MP. Awareness of About Breast Cancer among Dental Surgeons. 2016 [cited 2020 Jun 7]; Available from: https://www.semanticscholar.org/paper/Awarenessof-About-Breast-Cancer-among-Dental-Balaji-Brundha/63f441 73d90b35bffa33eed0aeb52ac547ef1567

33. Awareness of Polycystic Ovarian Disease among Females of Age Group 18-30 Years - ProQuest [cited 2020 Jun 7]. Available from: https://search.proquest.com/openview/a8a09e7b2e9d2f96 7bf3fee 479c7018a/1?pq-origsite $=$ gscholar\&cbl $=54977$

34. Varshini A, Rani SL, Brundha MP. Awareness of annual doctor checkups among general population. Drug Invention Today. 2020;14(2).

35. Ananya B, Rani SL, Brundha MP. Knowledge and attitude of probiotics among outpatients visiting dental operatory. Drug Invention Today. 2020;14(2).

36. Naveenaa N, Rani SL, Brundha MP. Knowledge, attitude, and perception on the importance of hematological report among general population. Drug Invention Today. 2020;14(2).

37. Reichal CP, Rani SL, Brundha MP. Occurrence of behavioral changes and its management in persons with mental illness due to lunar effects. Drug Invention Today. 2020;14(2).

38. Swetha G, Rani SL, Brundha MP. Awareness of the side effects of vaccination among general public. Drug Invention Today. 2020;14(3).

39. Dhivyadharshini J, Brundha MP. Comparison of effects of interpretation of lab reports among the undergraduate dental students. Drug Invention Today. 2020;14(3).

40. Brundha MP. A Comparative Study-The Role of Skin and Nerve Biopsy in Hansen's Disease. Res J Pharm Biol Chem Sci,2015; Available from: https://www.researchgate.net/profile/ Brundha_Mp/publication/283561218_A_comparative_studythe_role_of_skin_and_nerve_biopsy_in_hansen's_disease/ links/5892ba5d458515aeac946451/A-comparative-study-therole-of-skin-and-nerve-biopsy-in-hansens-disease.pdf 